\title{
Quando o capital vai às compras: direitos sociais, privatização e a acumulação capitalista
}

\section{Resumo}

A hipótese que temos trabalhado há algum tempo, nas pesquisas em curso, toma em análise, por ser determinante, a função econômica do Estado. Função econômica que no modo de produção capitalista sempre existiu, mas que se metamorfoseou no seu evolver e, atualmente, ocupa uma centralidade nos tempos de normalidade e nos momentos de crise que não se pode ignorar para a compreensão da acumulação capitalista na sua totalidade. A previdência social um direito da classe trabalhadora - é submetida a exóticas alterações para que se transforme no seu contrário - numa forma capital - é observada como fenômeno concreto para tentar atualizar modos de ser do Estado burguês em nossos dias.

Palavras-chave: Ajuste econômico-social. Acumulação capitalista. Capital fictício.

\section{Sara Granemann}

Universidade Federal do Rio de

Janeiro - UFRJ - Rio de Janeiro/RJ Brasil

sgranemann@ufrj.br

\section{Para citar este artigo:}

GRANEMANN, Sara. Quando o capital vai às compras: direitos sociais, privatização e a acumulação capitalista. Revista Linhas. Florianópolis, v. 21, n. 46, p. 50-71, maio/ago. 2020. 


\title{
When capital goes shopping social rights, privatization and capitalist accumulation
}

\begin{abstract}
The hypothesis that we have been discussing for some time, in researches already in course, takes the economic role of the State as a major factor. This role has always existed in the capitalist mode of production. However, the naturalization of a phenomenon hides its development and the possible metamorphoses of its mutations and new features. We notice that this economic role, both in times of normality and during crisis, cannot be ignored, under risk of not fully comprehending the capitalist accumulation on its entirety. The analysis of social security - which is a right owned by the labour class subjected to drastic changes so that it becomes the exact opposite - in a capital form - serves me as a concrete phenomenon for questioning the way in which the bourgeois state exists nowadays.
\end{abstract}

Keywords: Economic and social adjustment. Capitalist accumulation. Fictitious capital. 
Mas há sempre uma candeia dentro da própria desgraça há sempre alguém que semeia canções no vento que passa.

Mesmo na noite mais triste em tempo de servidão há sempre alguém que resiste há sempre alguém que diz não. (Manuel Alegre - Trova do vento que passa)

Nos dias presentes, é comum aos grandes burgueses e aos seus governos entoarem, à maneira de cântico devocional, os direitos sociais como entraves ao crescimento econômico. Revestem a relação puramente social entre crescimento econômico e direitos sociais da mesma força natural, do mesmo inescapável destino de as "pereiras a produzirem peras". Na mesma cansativa toada, as grandes mídias, igualmente propriedades de grandes capitais, repercutem e, não raro, acrescentam: os direitos prejudicam o crescimento econômico e são responsáveis pelo aumento do desemprego. A mistificação expressa na binária fórmula causa-consequência é esgrimida pela burguesia, à farta e ao modo de chantagem, contra a organização da classe trabalhadora com o fito de eliminar-Ihe a capacidade de reação. Paralisia alcançada com êxito quando a própria classe trabalhadora supõe que o desemprego e todos os demais padecimentos dele decorrentes são de sua estrita responsabilidade.

Diferentes formações sociais e distintos estágios de consciência da classe trabalhadora exigem da burguesia meios, argumentos, ideologias com níveis particulares de sofisticação. Funcionários dos grandes capitais difundem ${ }^{1}$ cansativa e repetidamente a impossibilidade de coexistência de empregos e direitos sociais e, por meio de publicações de alcance mundial, testemunham as reduções de postos de trabalho. Convicções científicas, difundidas sem a menor consideração pela mesma realidade na qual está em curso, na maioria dos países, a dramática extensão das jornadas de trabalho. A pressão sobre trabalhadores e trabalhadoras por meio da redução de postos de trabalho no modo

\footnotetext{
* A autora deste artigo é Bolsista Produtividade do CNPq.

1 Estruturada por argumentos das chamadas "agências multilaterais" que operam como internacionais de grandes capitais pela via de formulações político-econômicas elevadas à ciência absoluta e 'aplicáveis' em todos os quadrantes do planeta sem consideração por suas particularidades, exceto a de estarem todos submetidos ao modo de produção capitalista.
} 
de produção capitalista sempre foi utilizada como meio de controle das organizações da classe trabalhadora porque os capitais, ao dispensarem força de trabalho, conseguem rebaixar os salários do conjunto da classe trabalhadora.

Atualmente, mais do que em outros momentos - dadas as dificuldades de 0 próprio modo de produção se reproduzir na sua totalidade planetária ${ }^{2}$ a supressão de postos de trabalho e a concorrência intra-capitalista para repor e alargar suas taxas de lucro, exigem aos capitais o extermínio de direitos porque estes devem articular-se à lógica da acumulação como mercadorias. As políticas sociais operadas no modo de produção capitalista, ainda que provisórias e reversíveis, como ensinou Karl Marx, são vitórias conquistadas por lutas políticas do trabalho contra a economia política do capital; mas, contraditoriamente, a conquista de um direito para a classe trabalhadora (ou para algum de seus estratos e frações) é, quase sempre e pela mesma ação, também um ganho para o capital.

Netto (1992), em certeira análise, fez ver que, na idade monopolista, o Estado burguês deve incorporar algumas demandas dos de baixo. Conforme o autor:

[...] para exercer, no plano estrito do jogo econômico, o papel de 'comitê executivo' da burguesia monopolista, ele deve legitimar-se politicamente incorporando outros protagonistas sócio-políticos. 0 alargamento de sua base de sustentação e legitimação sócio-política, mediante a generalização e a institucionalização de direitos e garantias cívicas e sociais, permite-lhe organizar um consenso que assegura seu desempenho. (NETTO, 1992, p. 23)

A presente, grave e longa crise iniciada já há doze anos é de tal magnitude que os mecanismos de consenso têm sido destruídos com inédita violência até para os parâmetros do próprio modo capitalista de produção, violento desde o nascedouro - no centro e na periferia; é a necessidade imperiosa de o capital encontrar novos espaços de inversão para repor suas taxas de lucro que faz parecer terem os grandes capitais

\footnotetext{
${ }^{2}$ Para argumentos sobre os limites - inclusive - ambientais e climáticos dos dias que correm, ver: MÉSZÁROS, István. Produção destrutiva e estado capitalista. São Paulo: Ensaio, 1989. (Cadernos Ensaio. Pequeno formato; v.5); MÉSZÁROS, István. Para além do capital. São Paulo: Boitempo: Editora da UNICAMP, 2002 e BARRETO, Eduardo Sá. O capital na estufa: para a crítica da economia das mudanças climáticas. Rio de Janeiro: Consequência, 2018. (NIEP - Marx; v.4).
} 
decidido como seu padrão de normalidade para este tempo, pela via de seus Estados, absterem-se do momento coesionador que desde o segundo Pós-Grande Guerra puseram em curso.

São múltiplas as determinações para essa mudança de qualidade na ação dos Estados e, dentre elas, por oportuno recorde-se: a) o fim das economias do denominado socialismo realmente existente do Leste Europeu; b) as graves e permanentes crises do modo capitalista de produção em seu estágio mais desenvolvido - estágio no qual o paroxismo do apodrecimento da acumulação capitalista é pleno em sinais e sintomas. Apodrecimento já em curso que, por sua vez, e nunca automaticamente, pode se resolver em uma direção não progressista. Parece-nos evidente que essas afirmações não equivalem a dizer que os Estados capitalistas não tiveram e não terão, desde que se iniciou a grande crise em 2007/2008, no interior de seu escasso elenco de saídas, fugazes apegos à intervenção coesionadora e à democracia quando das lutas contra a classe trabalhadora.

Em outras palavras, a política social - tão inequívoca como insuficiente mediação do consenso, neste ambiente, cederá passo aos instrumentos de coerção como a política de enfrentamento da crise dos capitais por seus Estados e governos. Realizada uma tal tendência, haveria espaço para a existência de alguma "política social"? Supomos que existirá de modo tão diverso que pouco restará das forma e conteúdo presentes. Aos moldes de Friedman (1984), e especialmente nas ditas "economias em desenvolvimento", quando existir, será como mínimos sociais e sob a forma monetizada. A centralidade, neste cenário, não caberá à coesão pela via dos direitos sociais e do trabalho realizados por políticas sociais e proteção jurídica ${ }^{3}$, uma vez que os direitos terão de ser transmutados, cada vez mais, em “mercadorias”.

Ao horizonte de aumento dos já insuportáveis níveis de violência das políticas de extermínio diretas do aparelho repressivo estatal, como ações para o controle das crescentes miséria e exploração da classe trabalhadora, conjugam-se as "políticas" indiretas e admitidas, executadas por máfias, milícias, bandos de matadores de aluguel,

\footnotetext{
3 Inclusive a proteção previdenciária aos acidentes de trabalho transmutada em inteiro comércio pela via dos seguros privados.
} 
exércitos privados e toda a sorte de gangsterismo, combinada e complementar, oficial e para-oficial ao Estado 4 burguês.

Escusado seria dizer-se: a coerção como o consenso, no modo de produção capitalista, ambas têm seus limites postos pelas necessidades e dinâmicas essenciais ao modo de ser do modo capitalista de produção. Nessa medida, a dissolução dos instrumentos estatais de viabilização de direitos - políticas sociais e do conjunto de legislação trabalhista e seus instrumentos fiscalizadores e jurídicos - integram as saídas que os grandes capitais articulam para a resolução - sempre provisória - de suas crises econômicas. A violência como expediente ao enfrentamento das dificuldades econômicas quase sempre porta um impasse dramático: não pode ser a saída da classe trabalhadora para a crise política que o abandono do papel "coesionador" do Estado, fará (?) estalar.

Às turras com as contradições de sua própria condição de classe, a burguesia adjunta ao coro de seus sortidos argumentos: se até em países ricos urge reformá-los (aos sistemas de emprego e de direitos trabalhistas e sociais), no restante dos países a freima incontida dos lucros eleva-se ao ponto de tornar-se uma urgente necessidade. Dito de outro modo, é a imparável necessidade dos monopólios em "viabilizar um (seu) objetivo primário: o acréscimo dos lucros capitalistas através dos controles dos mercados." (Netto; 1992, p. 16) em tempos de bonança e, especialmente, nas crises cada vez mais frequentes que fazem a burguesia do puro capitalismo já não poder universalizar - ainda que nos seus estritos mecanismos ideopolíticos - o consenso e, tampouco, ser capaz de exercer a coerção de modo contínuo. Controlar mercados supõe o domínio da cultura, da política e da economia por interesses privados de uns poucos grupos econômicos e países sobre a maioria da humanidade.

A acirrada e, em alguma medida, recente disputa dos grandes capitais na monopolização de novos espaços de inversão no que fora em boa parte do século XX o âmbito do Estado 5 , metamorfoseia a res pública ${ }^{6}$ em assunto comercial - como o sempre

\footnotetext{
${ }^{4}$ Veja-se em DEMIER, Felipe. Crônicas do caminho do caos: democracia blindada, golpe e fascismo no Brasil atual. Rio de Janeiro: Mauad X, 2019, a instigante formulação ensaística da categoria democracia blindada oferecida pelo autor para a análise dos regimes políticos e Estados do tempo presente.

${ }^{5}$ Não se desconhece a inseparável unidade do momento produtivo do reprodutivo da vida social sob o capitalismo que tem no Estado um dos seus mais essenciais "instrumentos"de consolidação e manutenção da totalidade do modo de produção capitalista. O que se quer marcar é a mudança de qualidade nas funções do Estado, por ter agregado, mais do que em outro tempo, a conversão do fundo público em
} 
foi, mas agora sem véus - ao imutar o fundo público em espaços de mercantilização, em negócios que os convocam poucos grupos monopolistas em intestinas concorrências pelo controle do fundo público no interior das formações sociais. Trata-se aqui de um só fundo público existente sob diferentes formas: a) o fundo público resultante do trabalho passado, cristalizado em empresas estatais (produtivas, bancárias, de infraestrutura) e em equipamentos de políticas sociais (prédios, equipamentos) e nos direitos sociais mesmo; b) o fundo público formado no presente e que se realiza sob múltiplas formas, como as já citadas, dentre as quais nos interessa a porção destinada à política social viabilizadora de direitos sociais, todos os meses, no tempo corrente.

A lógica do modo de produção capitalista, acentuadamente dos anos de 1960 aos dias de agora, e mais do que sempre, demandou o fundo público recolhido pelo seu Estado para, em dias de crise e de "bonança", por 'múltiplas e criativas formas e fórmulas', contrarrestar a queda da taxa de lucros. O Estado fiador e garantidor universal da acumulação privada dos grandes capitais não pode renunciar à sua sorte, uma impossibilidade dada a sua essência mesma de classe, a burguesa.

\section{“Previdência privada" na crise e na prosperidade: um achado para os capitais}

A mal denominada "previdência privada" desenvolveu-se em relação à previdência pública com uma dependência inultrapassável; por ser complementar sua existência, articula-se à política social previdenciária em uma unidade de contrários. Seu propósito, por sua natureza complementar, reserva à previdência pública um bem guardado abraço

\footnotetext{
espaços de valorização. Ver: LÊNIN, Vladimir llitch. O estado e a revolução. São Paulo: Hucitec, 1983 e GRANEMANN, Sara. Capitalismo "puro", Estado e fundo público. In: TEORIA SOCIAL, FORMAÇÃO SOCIAL E SERVIÇO SOCIAL: pesquisas marxistas em debate. Rio de Janeiro: PPGSS UFRJ, 2018. (Coleção Carlos Nelson Coutinho; v. iv).

6 "Concebida ainda na Antiguidade Clássica, adotada depois em Roma e em alguns regimes medievais, essa forma de governo ganhou uma estrutura sólida e institucional a partir da Revolução Norte-Americana de 1787. Baseia-se, conceitualmente, na chefia do Estado por representantes dos interesses populares, e não de famílias (por transmissão hereditária, como na monarquia) ou detentores do poder militar. Nos regimes democráticos, essa chefia determina-se com a eleição do chefe de Estado pelo povo, em voto direto ou através de uma assembleia eleita pelo povo. A república pode ser presidencialista ou parlamentarista (ver achegas nos verbetes parlamentarismo e presidencialismo.) Há também sistemas mistos, com maior ou menor concentração de poder no presidente. O Brasil é uma república desde 1889". Caldas Aulete Digital. http://www.aulete.com.br/república (Consulta em 10 novembro 2019).
} 
de morte . Contrários por ser uma previdência pública porque política social, solidária, repartida, coletiva, direito social; a outra, uma não previdência, um investimento bancário-financeiro, privado, capitalizado, individual, um não direito que para crescer nutre-se do amesquinhamento do direito, da destruição do seu contrário: a previdência social. O destino da "previdência completar" pesa como cruz sobre as costas da previdência pública; o êxito da primeira, a adesão de massas trabalhadoras a uma falsaprevidência está hipotecada à destruição deste direito social estruturado sobre a ideia e prática de solidariedade entre os iguais. Pesa por ser mais uma das muitas soluções encontradas pelos capitais para se alimentarem da vida que roubam da classe trabalhadora.

Destruir esse exercício de solidariedade entre iguais, impossibilitar a repetição de um aprendizado de repartição em uma situação concreta, incide sobre os estágios de compreensão e construção da classe como classe para si. É um direito que não se esgota em si mesmo por carregar lutas dos trabalhadores e trabalhadoras que vêm de muito longe: remonta aos primeiros enfrentamentos de desgraças reconhecíveis em comum e que em 1848 se fizeram estrondoso aprendizado. A negação da previdência social como extinção e rebaixamento do direito social revela sua unidade contraditória com o seu diverso: os investimentos financeiros que podem ser investimentos bancário-financeiros de múltiplas formas, mas que jamais serão previdência no sentido a ela conferido pela luta da classe trabalhadora. Não o serão, inclusive porque a "previdência privada", a capitalização, tem sua origem na incessante busca de lucratividade dos capitais e com esse objetivo foi por eles criada.

As aposentadorias e pensões são políticas sociais construídas no âmbito das lutas de classe e suas protoformas remontam aos dias da Comuna de Paris com o fito de proteção à força de trabalho em sua velhice e em situações excepcionais (por acidente laboral, por incapacitação por doença, por guerras) que impedem as trabalhadoras e os trabalhadores da continuidade do exercício laboral.

\footnotetext{
7 "Abraço da Morte é um fenômeno que observamos na natureza entre dois vegetais, um que serve de hospedeiro e o outro de hóspede, que necessita se desenvolver ao fixar no caule do hospedeiro, permitindo a emissão de suas raízes, que servirão de apoio quando adulto, de tal forma que suas raízes se tornarão frondosas e fortes, comprometendo a vida de seu hospedeiro [... ]. É um vegetal que cresce sobre outras árvores lançando suas raízes aéreas em direção ao solo, e a medida que cresce, desenvolve um sistema radicular resistente para melhor apoiar quando se tornar adulto e frondoso[...]" http://bosque.inpa.gov.br/bosque/index.php/abraco (consulta em 02.08.2019).
} 


\section{Previdência social no Brasil - os dois regimes públicos}

Oganiza-se por solidariedade - nominação que nos parece mais adequada - e sua outra designação 'técnica', por repartição, guarda igual princípio político. Típica de sistemas públicos realizadas como políticas sociais, a solidariedade na estruturação da previdência social remonta aos dias de lutas da classe trabalhadora na Paris vermelha e insurgente de 1871. Mais tarde, cerca de 3/4 de século depois, também ao findar de uma guerra - a Segunda Grande Guerra Mundial (1939-1945) -, ganham consistência os arranjos públicos de previdência desenvolvidos em vários países pelo planeta. Seu evolver foi lento e difícil como sói ocorrer com os direitos de trabalhadoras e trabalhadores; tão difícil, que as lutas por previdência social talvez somente encontrem paralelo em termos de dificuldades para serem alcançadas, com as enfrentadas pela classe trabalhadora para a redução da jornada de trabalho. As políticas socias desenvolvidas em solo europeu no Segundo Pós-Guerra foram tomadas por referência por muitos países para a construção do que se convencionou chamar Estado social ou Estado de bem-estar social.

No Brasil, integram o sistema previdenciário público dois diferentes regimes: 1) o Regime Geral de Previdência Social (RGPS); destina-se à força de trabalho autônoma, doméstica, à agricultura familiar, extrativistas, pequenos pescadores, a empregada por diferentes capitais rurais e urbanos e a empregada pelo Estado no momento municipal quando não houver RPPS. 2) o Regime Próprio de Previdência Social (RPPS) destinado à força de trabalho empregada pelo Estado nos seus diferentes momentos (município, estado e união) $)^{8}$.

\footnotetext{
8 Desde a posse do governo Bolsonaro, o Ministério da Previdência Social deixou de existir e foi transformado em uma das dez Secretarias existentes no Ministério da Economia, comandado por Paulo Roberto Nunes Guedes. A Secretaria Especial de Previdência e Trabalho substitui os Ministério da Previdência e o do Trabalho e subdivide-se em Secretaria de Previdência (formada por quatro subsecretarias, a saber: 1) Subs. do Regime Geral de Prev. Social, 2) Subs. dos Regimes Próprios de Prev. Social, 3) Subs. do Regime de Prev. Complementar, 4) Subsecretaria da Perícia Médica Federal) e Secretaria de Trabalho (constituída por três subsecretarias: 1) Subs. de Inspeção do Trabalho, 2) Subs. de Pol. Públicas e Rel. do Trabalho, Subs. de Assuntos Corporativos). Disponível em: <https://www.gov.br/economia/ptbr/imagens/organograma_v11.pdf/>. Acesso em: 21 jul. 2020.

Dados da anterior estrutura do Ministério da Previdência informavam existir 2.130 RPPS assim distribuídos: 01 Federal, 27 de Estados e Distrito Federal e 2.102 Municipais. Disponível em: <http://www.antigo.previdencia.gov.br>. Acesso em: 21 jul. 2020.
} 


\section{“Previdência privada” e sua natureza não previdenciária}

A “previdência privada” (BRASIL, 1977) foi estabelecida pela Lei $n^{\circ} 6.435$, de 15 de julho de 1977, em plena ditadura do grande capital e foi sancionada pelo ditador de plantão, o General Ernesto Geisel e por Luís Gonzaga do Nascimento e Silva, seu Ministro da Previdência Social9. No Brasil, como em vários países nos quais a "previdência complementar" foi implementada, ela resultou de um ato de força: ou de governos ditatoriais, de que o Chile é o caso clássico ${ }^{10}$ ou como imposição após derrotas de greves e outros movimentos da classe trabalhadora; derrotas, muitas vezes articuladas por direções da classe trabalhadora afeitas à proximidade dos grandes capitais e de seus Estados, por exemplo quando de seu surgimento nos Estados Unidos. A conclusão que salta aos olhos é uma só: a previdência social teve origem nas lutas e necessidades da classe trabalhadora; a "previdência privada", a não previdência, surgiu para ser um instrumento decorrente da urgência dos capitais em amealhar as individualmente parcas economias da classe trabalhadora que, reunidas, tornam-se riquezas extraordinárias e são operadas como capital. Aqui, marcar o óbvio é um dever: reunião de poupança da classe trabalhadora como capital - a "previdência privada" cujos movimentos serão sempre contrários aos próprios "poupadores".

A “previdência privada” organiza-se por capitalização e é operada por instituições bancário-financeiras, empresas do mercado de capitais e corretoras. Nos países nos quais o sistema complementar de "previdência privada" existe é, em geral, desdobrado em duas formas básicas: 1) as Entidades Fechadas de Previdência Complementar - EFPC, também denominadas fundo de pensão ("pension fund"). Nela estão, em tese por escolha autônoma ${ }^{11}$, trabalhadoras e trabalhadores de uma dada categoria profissional

\footnotetext{
9 Luís Gonzaga do Nascimento e Silva, por duas vezes ministro na ditadura do grande capital: sob os governos ditatoriais de Humberto de Alencar Castelo Branco, de agosto de 1966 a março de 1967, ocupou a pasta do Trabalho e Previdência Social e, de Ernesto Geisel, de julho de 1974 a março de 1979, o Ministério da Previdência e Assistência Social.

${ }^{10} \mathrm{~A} 13$ de novembro de 1980, publicou-se no Diário Oficial o Decreto Lei $\mathrm{N}^{\circ} 3.500$ que estabeleceu o NUEVO SISTEMA DE PENSIONES e Criou o REGIMEN DE PREVISION SOCIAL DERIVADO DE LA CAPITALIZACION INDIVIDUAL (CHILE, 1980). A 13 setembro de 1973, teve lugar no Chile o golpe do grande capital contra o governo popular de Salvador Allende. A seguir, instalou-se cruenta ditadura no país e que operou a destruição da previdência social chilena, encabeçada por Augusto Pinochet. Desde então, o Chile é o caso clássico, embora a "previdência privada" dita por capitalização tenha sido imposta em 1981, depois de sua implantação no Brasil, também pela ditadura do grande capital.

${ }^{11}$ As Entidades de "previdência complementar" sejam abertas ou fechadas, por serem instrumentos dos
} 
(por exemplo: petroleiros, bancários, servidores públicos), contratada como força de trabalho por uma ou mais empresas, em geral do mesmo ramo. Aqui a forma individualista, privada, de “proteção previdênciária", na aparência, está envolvida pelo véu de uma categoria profissional. Essa ilusão leva trabalhadores e trabalhadoras a agir como se a existência de um conjunto de trabalhadores individualmente cotistas constituisse, naturalmente, uma forma solidária e realmente previdenciária. Não o é, inclusive porque cada trabalhadora/or, ao cumprir individualmente as exigências do (seu) contrato, não tem garantias de que terá os rendimentos prometidos no ato da compra dessa mercadoria. Se os tiver, se os seus investimentos resultarem exitosos depois de um largo período de vida, suas contribuições vertidas à conta individual poderão ter sorte diversa da de outros trabalhadores, seus iguais, em salários, tempo de contribuição e período histórico em que "pouparam" a uma mesma forma de "previdência privada". Os resultados poderão ser diversos porque suas contas são também diversas. 2) Entidades Abertas de Previdência Complementar - EAPC, ou simplesmente a "previdência complementar aberta", predominantemente mercadorias negociadas, vendidas por bancos e seguradoras, para indivíduos trabalhadores atomizados que a contratam - aqui a venda se reveste de contrato, aplicação, capitalização - por longo tempo e que tem na propaganda para torná-la uma mercadoria atrativa, cálculos sobre o futuro que acenam com expectativas de "retorno" financeiro para os compradores sempre muito acima e além do que a vida real permite alcançar.

Fundos de pensão, fundações de seguridade, "previdência" complementar são instrumentos privados e, mesmo que instituídos para trabalhadoras/es empregada(o)s em empresas estatais, não são públicas porque a responsabilidade da empresa consiste somente em fazer a sua contribuição como patrão. Em caso de quebra, não há responsabilidade da empresa e do Estado em salvar ou repor os valores desaparecidos; movem-se por lógica individual; nela, cada trabalhador deve precaver-se, isolado e solitariamente, no provimento das condições para sua futura velhice. Aqui importa notar:

\footnotetext{
mercados de capitais não podem ser de contribuição obrigatória e, por isso, tanto na Constituição da República Federativa do Brasil, como nas regulamentações e fichas de filiação, elas reconhecem sua natureza facultativa. Veja-se na Carta Magna, o Art. 202: "O regime de previdência privada, de caráter complementar e organizado de forma autônoma em relação ao regime geral de previdência social, será facultativo, baseado na constituição de reservas que garantam o benefício contratado, e regulado por lei complementar." (BRASIL, 1998).
} 
o estímulo para comprar e consumir uma aposentadoria privada realiza-se no plano individual, mas a condição de classe é mesmo incontornável e, pela via de mistificações, a mercadoria que a substituir o direito tem de lhe tomar o nome, não pode renunciar a se chamar "previdência” ainda que sua adjetivação revele o seu conteúdo, sabemos que a mistificação tem força material.

Ambas as formas de "previdência" complementar realizam-se por meio de investimentos no mercado de capitais e são sistemas privados de aplicação financeira, capitais fictícios derivados de capitais portadores de juros, prioritariamente alocados em duas frentes: 1) na compra de títulos públicos dos Estados pelo planeta; em tempos de graves crises econômicas, os títulos mais seguros são os daqueles Estados que conseguem combinar ambientes sociais que garantam exploraçãoo elevada da força de trabalho, controle sobre a luta de classe e juros substantivos. Os recursos para remunerar os (proprietários dos) títulos públicos com juros altos provêm do fundo público recolhido e gerido pelo Estado, na imediaticidade da vida social, como impostos e contribuições sociais; na essência, sempre e tão somente, riqueza produzida pelo trabalho. Por trabalho excedente (base da mais-valia) expropriado dos trabalhadores pelo capital e cuja ínfima parte é recolhida ao Estado, por exemplo para a Seguridade Social, como impostos sobre o lucro. Por trabalho necessário, (assume a forma de salário) pela sucção cada vez mais alargada de impostos sobre o consumo e de contribuições sociais recolhidas da classe trabalhadora ao mesmo Estado burguês. O fundo público recolhido sob a forma monetária materializa-se em obras estatais como empresas, estradas e pontes; na reprodução da vida dos trabalhadores por meio de hospitais, escolas e aposentadorias; mas, também, porções crescentes deste fundo têm assumido a forma de juros transferidos aos grandes capitais detentores dos títulos públicos que, do ângulo do Estado que os remunera, é a sua dívida pública.

Para que este vertedouro de riquezas se reproduza na direção dos capitais há que, permanentemente, diminuir os montantes destinados à reprodução social da vida da classe trabalhadora para aumentar a porção destinada aos credores do Estado ${ }^{12}$. Nessa

\footnotetext{
12 Exemplo bastante da drámatica redivisão do fundo público do Estado brasileiro é a Emenda Constitucional $n^{\circ}$ 95/2016 que, enquanto tramitava como Proposta de Emenda Constitucional $n^{\circ}$ 55/2016, foi denominada PEC do "fim do mundo" para caracterizar a imposição de um ajuste que conduz ao austericídio. Por austericídio, queremos expressar o impacto profundo que as políticas econômicas
} 
equação, a redução dos direitos sociais pela via das contrarreformas (trabalhista, previdenciária, educação, saúde, etc), da limitação de gastos sociais, constituem as privatizações clássica e não clássica do fundo público (Granemann, 2012) que são, ao mesmo tempo, produto e condição da transferência do fundo público aos grandes capitais; resultado e exigência da acumulação dos capitais mediada e garantida por seu Estado. Os detentores desses títulos são os grandes investidores, especuladores, bancos, seguradoras, capitalistas de todas as espécies, fundos de pensão. Ao 'conjunto da obra' denominam "previdência" complementar (aberta e fechada); na crítica da vida concreta o sabemos capital fictício, capitalização.

A formação do capital fictício chama-se capitalização. Cada receita que se repete regularmente é capitalizada em se a calculando na base da taxa média de juros, como importância que um capital, emprestado a essa taxa de juros, proporcionaria; [...]. Toda a conexão com o processo real de valorização do capital se perde assim até o último vestígio, e a concepção do capital como autômato que se valoriza por si mesmo se consolida. [...]. Do que não se exclui, de modo algum, a possibilidade de que representem mera fraude. Mas este capital não existe duplamente, uma vez como valor-capital dos títulos de propriedade, das ações, e outra vez como capital realmente investido ou a investir naquelas empresas. Ele existe apenas nesta última forma, e a ação nada mais é que um título de propriedade, pro-rata, sobre a mais-valia a realizar por aquele capital. (MARX; 1983, p. 11, grifo nosso)

Trabalhadoras/es participantes da "previdência privada" aberta ou fechada - ainda que não o saibam - por meio de investimentos que estes instrumentos dos capitais realizam em títulos públicos, contribuem para a realização das contrarreformas e, assim, com a diminuição das políticas sociais impostas por ajustes, pela formação de superávits e para a abertura de novos espaços de mercantilização do que fora direito social. 2) na compra de ações de empresas mais lucrativas. Ao associar-se ao fundo de pensão ou a uma "previdência privada" - aberta ou fechada - em busca de uma melhor

alicerçadas no ajuste de gastos sociais promovem sobre trabalhadores/as; as medidas de austeridade são tão profundas que provocam a morte de trabalhadores e trabalhadoras ao retirar-lhes proteção social, emprego e dignidade humana, e por tão dolorosas e amesquinhadas pelo desejo do lucro dos grandes capitais e de seus governos, acabam por destruir, também, economias e países. Ver: BRASIL. Presidencia da República. Emenda constitucional $n^{\circ}$ 95, de 15 de dezembro de 2016. Altera o Ato das Disposições Constitucionais Transitórias, para instituir o Novo Regime Fiscal, e dá outras providências. [Brasília, DF: Presidência da República], 2016. Disponível em: <http://www.planalto.gov.br/ccivil_03/constituicao/Emendas/Emc/emc95.htm>. Acesso em: 15 fev. 2020. 
aposentadoria, trabalhadoras/es renunciam a uma parte do salário e a poupam como “previdência privada”. Pequenas porções de dinheiro juntam-se às contribuições mensais de outros milhares de trabalhadores e são transformadas em uma gigantesca massa de recursos em busca de investimentos.

Tais investimentos, além de títulos públicos, concentram-se em ações lucrativas de empresas privadas, estatais ou ex-estatais. Para serem lucrativas, as empresas devem extrair trabalho não pago dos trabalhadores pela elevação da jornada de trabalho, por produzirem mais no mesmo tempo de trabalho ou por reduzirem-lhes o valor da sua força de trabalho. O trabalho não pago é o que constituirá, o que se tornará o lucro dos capitais. Uma “previdência” privada, complementar, um fundo de pensão, um PGBL, um VGBL, deve investir em empresas que apresentem níveis de lucratividade mais elevados, naquela que mais explore os trabalhadores porque só assim os recursos renunciados, mês a mês ao longo de anos e décadas, pelo trabalhador, em favor de um investimento convertido em capital, poderá crescer não como "previdência”, mas como capital. Daí ser denominada capitalização. Investimentos estes que, quando alcançam êxito, têm uma contra-face perversa: a pequena poupança de uns trabalhadores transmutada em capital tem de agir como capital: deve aplicar-se a extrair trabalho não pago, deve expandir o desemprego de muitos outros trabalhadores substituídos por máquinas, por trabalhadores com contratos precarizados e com salários mais baixos. A capitalização, em sua permanente busca de lucros, aceita a destruição da natureza humana e da ambiental, potencializa o sofrimento no trabalho por buscar o lucro e destruir sonhos, vidas e possibilidades para as gerações futuras, no interior das quais poderão estar filhos e netos daqueles e daquelas portadores/as de “previdência privada”.

\section{"Previdência complementar": um achado da acumulação capitalista}

A afirmação de que a "previdência privada" é complementar à previdencia pública possibilitou, desde o momento de sua criação, e na continuidade de sua expansão - no Brasil e alhures - mobilizar parte da direção (partidária e sindical) da classe trabalhadora na defesa de sua adesão. Esse achado do capital - a "previdência privada" é sua invenção - não teria vida tão facilitada, talvez nem mesmo pudesse existir, não fossem os Estados 
dos capitais arregimentarem as alterações nos direitos sociais e o ambiente favorável para o crescimento de um tal negócio. Ao achado capitalista, foi indispensável ao inventor dar-lhe tintas de benefícios à classe trabalhadora. Mais ainda: a conexa condição de aniquilamento da previdência pública como solo ao crescimento da "previdência privada" não se pode revelar; ao contrário, é razão suficiente para que busquem desvencilhar a destruição da previdência social (em seus dois regimes) como condição incontornável ao desenvolvimento da "previdência privada".

Em nosso país, verificamos um continuum nas seis grandes contrarreformas realizadas contra o sistema previdenciário público, ocorridas desde a aprovação da Constituição da República Federativa do Brasil de 1988. A mobilização de argumentos para as contrarreformas da previdência pública, materializadas nas sucessivas Emendas à Carta Magna, repetiram argumentos de déficit, privilégios, envelhecimento demográfico, vagabundagem, irresponsáveis com o futuro dos jovens, destruidora da 'empregabilidade' e da economia dentre tantos outros colecionáveis absurdos e hipocrisias.

Na primeira contrarreforma, instituída pela Emenda Constitucional $n^{\circ} 3 / 93$, de 17 de março de 1993, sob o governo de Itamar Franco, instituiu-se a obrigatoriedade da contribuição da força de trabalho empregada pela União para fins de aposentadoria e pensões (BRASIL, 1993). A Segunda contrarreforma foi de responsabilidade do governo de Fernando Henrique Cardoso, pela Emenda Constitucional $\mathrm{n}^{\circ} 20$ de 16 de dezembro de $1998^{13}$. Suas principais investidas sobre os direitos foram: no RGPS (Regime Geral de Previdência Social) extinguir aposentadorias proporcionais e instituir idade mínima para a aposentação em 48 anos para as mulheres e 53 anos para os homens e, por Lei Complementar, o Fator Previdênciário, que reduziu valores para a aposentadoria e as pensões e elevou o tempo de contribuição e de trabalho. Nos RPPS (Regime Própria de Previdência Social), estabeleceu: aposentadorias voluntárias serão admitidas cumpridos o tempo mínimo de dez anos de efetivo exercício no serviço público e cinco anos no cargo, aos 60 anos de idade e 35 de contribuição, se homem, e 55 anos de idade e 30 de contribuição, se mulher; fim da redução de cinco anos na idade e no tempo de

\footnotetext{
13 Antes disso, lia-se na redação da Constituição de 1988, o artigo 201, $\S 7$ "A previdência social manterá seguro coletivo, de caráter complementar e facultativo, custeado por contribuições adicionais (BRASIL, 1988).
} 
contribuição para professores do magistério superior e introdução da "previdência privada" na Constituição Federal no Artigo 40, relativo à aposentadoria da força de trabalho empregada pelo Estado. Nem cinco anos tinham se passado da contrarreforma anterior, o governo de Luiz Inácio Lula da Silva, ao capricho de sua enorme popularidade, nos seus primeiros meses, encaminhou ao Congresso Nacional uma Proposta de Emenda à Constituição. A publicação da duríssima Emenda Constitucional de n 41/2003 se deu em 30 de dezembro de 2003. A referida emenda deitou por terra algumas das cláusulas que se entendiam como Pétreas na Lei Maior do país. Para o RPPS: imposição da contribuição aos aposentada(o)s e pensionistas e estabeleceu que o teto do RGPS vinculava-se - sem o menor pudor - à criação da "previdência privada" para a força de trabalho empregada pelo Estado (BRASIL, 2003). A possibilidade, em construção nos governos de Franco e de Cardoso, tornara-se realidade que apenas precisaria ser formalizada por lei ordinária do executivo.

Doravante, a política social de previdência estaria, sem tréguas, sob a contínua cobiça dos capitais. A quarta Emenda Constitucional, de $n^{\circ} 47$, publicada em 06 de julho de 2005, também foi levada a termo no governo de Lula. Emenda que tentou suavizar as atrocidades cometidas na EC 41/2003 do mesmo governo, criou critérios diferenciados relativos às pessoas deficientes, para quem realiza trabalhos em condições especiais prejudiciais à saúde e de risco, e a figura jurídica de contribuinte de baixa renda com incidência sobre o trabalho doméstico realizado na própria moradia da trabalhadora/or, nos seguintes termos:

Artigo 201 - § 12. Lei disporá sobre sistema especial de inclusão previdenciária para atender a trabalhadores de baixa renda e àqueles sem renda própria que se dediquem exclusivamente ao trabalho doméstico no âmbito de sua residência, desde que pertencentes a famílias de baixa renda, garantindo-lhes acesso a benefícios de valor igual a um salário-mínimo. (BRASIL, 2005)

A Emenda Constitucional de $n^{\circ} 70 / 2012$, sexta relativa a assuntos de aposentadoria desde sua promulgação em 1988, foi sancionada no governo de Dilma Rousseff e institui a revisão das aposentadorias para trabalhadoras/es e reconhece-Ihes o direito a proventos de aposentadoria com base na remuneração do cargo em que ocorreu a aposentadoria (BRASIL, 2012). Em 08 de maio de 2015, também por contrarreforma da Presidenta Dilma 
Rousseff, ocorreu nova alteração da Constituição: a sexta Emenda Constitucional em torno do tema previdência social. A EC n 88 alterou a idade para a aposentaria compulsória da força de trabalho empregada pelo Estado ao elevá-la de 70 para 75 anos de idade (BRASIL, 2015).

Antes de consolidar-se sua deposição, a presidenta Dilma Roussef realizou um esforço de incidir sobre os articuladores que a bruta maioria branca, masculina, machista e servil aos grandes capitais não consumasse o golpe jurídico-parlamentar que lhe destituiu do cargo. Antes que esses movimentos se realizassem, a presidenta, no campo da política de previdência social, constituiu ${ }^{14}$ o Fórum de Debates sobre Políticas de Emprego, Trabalho e Renda e de Previdência Social, que incluiu centrais sindicais (com exceção da CSP- Conlutas), confederações dos capitais, governo e assessoria do DIEESE. O diagnóstico consignado em cento e noventa e quatro slides não aponta "soluções", mas assume a disseminada cultura da crise já denunciada em Mota (1995). Ao olhar no retrovisor, enxergamos com mais limpidez: o resultado elaborado no Fórum, espaço privilegiado ao exercício da conciliação de classes, foi a conclusão de déficit na previdência pública - em ambos os regimes. A síntese dos debates do Fórum foi recolhida como embasamento da PEC 287/1615, proposta por Michel Temer, vice-presidente da mandatária impedida, ele mesmo um dos artífices do golpe, isto é, na reafirmação do déficit.

Ao longo de 2017, o governo de Temer não conseguiu a votação da PEC. Denúncias de corrupção centradas no então governante e em seus próximos e de confiança, a proximidade das eleições e os custos de realizar uma reforma contra a classe trabalhadora e as lutas sociais enterraram as possibilidades de uma contrarrreforma da previdência, uma vez que uma feroz contrarreforma trabalhista foi votada e implementada. Não houve condições para que essas duas grandes agressões, articuladas

\footnotetext{
${ }^{14}$ Conforme o Decreto no 8.443, de 30 de abril de 2015: BRASIL. Decreto no 8.443, de 30 de abril de 2015. Institui o fórum de debates sobre políticas de emprego, trabalho e renda e de previdência social. [Brasília, DF: Presidência da República], 2015. Disponível em: <https://www.jusbrasil.com.br/topicos/34544714/decreto-n-8443-de-30-de-abril-de-2015>. Acesso em: 20 set. 2015.

${ }^{15}$ BRASIL. Proposta de emenda à constituição n. ${ }^{\circ}$ 287, de 2016. Altera os arts. 37, 40, 109, 149, 167, 195, $201 \mathrm{e}$ 203 da Constituição, para dispor sobre a seguridade social, estabelece regras de transição e dá outras providências. [Brasília, DF: Presidência da República], 2016. Disponível em: <https://www.camara.leg.br/proposicoesWeb/prop_mostrarintegra?codteor $=1527338 \&$ filename $=E M C+3 / 201$ 7+PEC28716+\%3D\%3E+PEC +287/2016>. Acesso em: 02 mar. 2017.
} 
contra os direitos da classe trabalhadora, fossem aprovadas em um governo que estava com os dias contados. Evidente que se as realizasse, pouparia o desgaste para o governo seguinte.

O doloroso e sombrio episódio do assalto aos direitos previdenciários hoje em curso, desenrola-se sob o despotismo do iletrado capitão Bolsonaro, presidente do país que comanda uma inacreditável equipe de ministros e assessores; equipe que parece ter em comum o exagerado apego, uma militância radicalizada, em rudeza e grosseria, além da desavergonhada entrega de riqueza que não lhes pertence aos grandes capitais. Este governo, com um já escolado ministro da economia, perito em aplainar as vias de privatização de tudo o que é estatal em nome de interesses econômicos - também são os seus - encaminhou uma PEC 06/2019 ${ }^{16}$ ao Congresso em 20 de fevereiro de 2019, para contrarreformar a previdência social, nos seus dois regimes.

Da longa trajetória que se abriu nos anos seguintes à feitura da Carta Magna de 1988, os grandes capitais e seu Estado anotaram os recursos previdenciários públicos como uma fonte crescente de patrimônio monetário acumulado como obra coletiva da classe trabalhadora, generosa e voluntariamente, com seu acordo e protagonismo. $\mathrm{O}$ instrumento para metamorfosear essa enorme riqueza social, poupança da classe trabalhadora, em mercadoria já estava constituído, mas era ainda, até a década de 1990, pouco expressivo em face de suas possibilidades de crescimento. Uma pedra, na verdade uma barreira gigante aos moldes da cadeia montanhosa andina, no caminho: a previência social, pública, recém construída como uma das poucas vitórias da classe trabalhadora acumulada pelas lutas sociais no final da ditadura do grande capital. Sem mover ou remover o que para os capitais é um gigantesco obstáculo, não haveria como transformar as reservas monetárias da classe trabalhadora em combustível da acumulação; uma mudança qualitativa precisa ser operada para que essa enorme riqueza social "mudasse de mãos" e de natureza. Dito de modo diverso, sem cumprir a exigência de que a previdência social, por solidariedade, fosse aviltada em mercadoria, controlada, vendida,

\footnotetext{
16 BRASIL. Proposta de emenda à Constituição n.06 de 20 de fevereiro de 2019. Modifica o sistema de previdência social, estabelece regras de transição e disposições transitórias, e dá outras providências. [Brasília, DF: Presidência da República], 2019. Disponível em: <https://legis.senado.leg.br/sdleggetter/documento?dm=7987584\&ts=1586467720440\&disposition=inline >. Acesso em: 20 fev. 2019.
} 
realizada pelos grandes capitais, não seria possível integrá-la majoritária e de modo contínuo e permanente, nos liames da acumulação capitalista.

Gráfico 01 - Ativos do Sistema de "Previdência Privada"

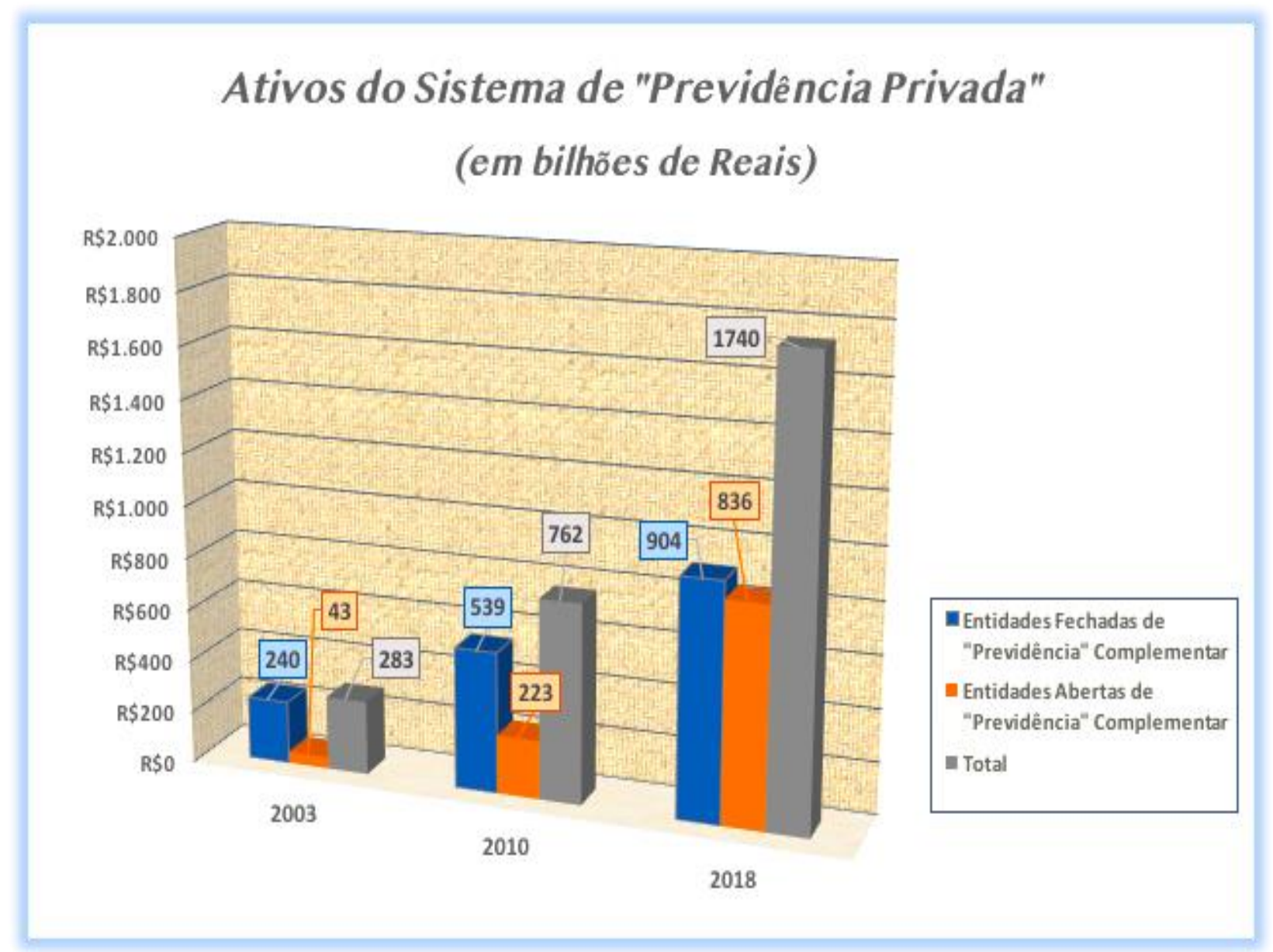

Fonte: SESUP, SPC, PREVIC, ABRAPP e FENAPREVI. (Elaboração própria)

À guisa de conclusão, há que se enfatizar: as contrarreformas na previdência pública determinaram o robusto crescimento da "previdência privada". 
Quadro 1 - Crescimento dos Ativos "Previdência Privada 2003/2018

Crescimento dos Ativos Totais no período de 2003 a 2018

Período

2003-2018

\begin{tabular}{|c|c|}
\hline $\begin{array}{c}\text { Entidades Fechadas } \\
\text { de Previdência } \\
\text { Complementar }\end{array}$ & $\begin{array}{c}\text { Entidades Abertas de } \\
\text { Previdência }\end{array}$ \\
\hline
\end{tabular}

Total - Entidades Fechadas e Abertas de Previdência Complementar

\footnotetext{
Fonte: SESUP, SPC, PREVIC, ABRAPP e FENAPREVI. (Elaboração própria)
}

No período, conforme dados acima, impressionam os níveis de crescimento e, talvez, seja possível afirmar-se: poucos negócios cresceram tanto pelo mundo como esse no Brasil. Crescimentos da acumulação capitalista, sempre e novamente, alimentados pela vida da classe trabalhadora. Vida transferida para a formação do lucro, vida dos capitais alimentada de fome, de dores, doenças, violência de tantas formas, machismo, racismo, todos visíveis nas necessidades das contrarreformas justificadas com argumentos morais, ideológicos, "científicos"... A razão pode ser muito mais simples: necessidades de lucros crescentes pela expropriação dos direitos sociais, do salário e da vida da classe trabalhadora.

\section{Referências}

BRASIL. Constituição da república federativa do brasil de 1988. [Brasília, DF: Presidência da República], 1988. Disponível em

<http://www.planalto.gov.br/ccivil_03/constituicao/constituicao.htm>. Acesso em: 20 mar. 2019.

BRASIL. Emenda Constitucional de $n^{\circ} 70$ de 29 de março de 2012. Acrescenta art. $6^{\circ}-A$ à Emenda Constitucional $n^{\circ} 41$, de 2003, para estabelecer critérios para o cálculo e a correção dos proventos da aposentadoria por invalidez dos servidores públicos que ingressaram no serviço público até a data da publicação daquela Emenda Constitucional. [Brasília, DF: Presidência da República], 2012. Disponível em <http://www.planalto.gov.br/ccivil_03/constituicao/Emendas/Emc/emc70.htm>. Acesso em: 20 fev. 2020. 
BRASIL. Emenda Constitucional $n^{\circ} 88$ de 7 de maio de 2015. Altera o art. 40 da Constituição Federal, relativamente ao limite de idade para a aposentadoria compulsória do servidor público em geral, e acrescenta dispositivo ao Ato das Disposições Constitucionais Transitórias. [Brasília, DF: Presidência da República], 2015. Disponível em: <http://www.planalto.gov.br/ccivil_03/constituicao/Emendas/Emc/emc88.htm>. Acesso em: 04 mar. 2020.

BRASIL. Lei n 6.435, de 15 de julho de 1977. Dispõe sobre as entidades de previdência privada, e dá outras providências. [Brasília, DF: Presidência da República], 1977. Disponível em:

<https://www.camara.leg.br/proposicoesWeb/prop_mostrarintegra?codteor=416917>. Acesso em: 25 nov. 2000.

BRASIL. Emenda Constitucional de $n^{\circ} 41 / 2003$ foi a 30 de dezembro de 2003. Modifica os arts. 37, 40, 42, 48, 96, 149 e 201 da Constituição Federal, revoga o inciso IX do § 3 do art. 142 da Constituição Federal e dispositivos da Emenda Constitucional $n^{\circ} 20$, de 15 de dezembro de 1998, e dá outras providências. [Brasília, DF: Presidência da República], 2003. Disponível em:

<http://www.planalto.gov.br/ccivil_03/constituicao/Emendas/Emc/emc41.htm>. Acesso em: 25 fev. 2004 .

BRASIL. Emenda Constitucional n $^{\circ} 20$ de 16 de dezembro de 1998. Modifica o sistema de previdência social, estabelece normas de transição e dá outras providências. [Brasília, DF: Presidência da República], 1988. Disponível em:

<http://www.planalto.gov.br/ccivil_03/constituicao/Emendas/Emc/emc20.htm>. Acesso em: 05 maio 2000.

BRASIL. Emenda Constitucional ${ }^{\circ}$ 3/93, de 17 de março de 1993. Altera os arts. 40, 42, 102, 103, 155, 156, 160, 167 da Constituição Federal. [Brasília, DF: Presidência da República], 1993. Disponível em:

<http://www.planalto.gov.br/ccivil_03/constituicao/Emendas/Emc/emc03.htm>. Acesso em: 25 fev. 2004.

BRASIL. Emenda Constitucional, de $n^{\circ} 47$ publicada a 06 de julho de 2005. Altera os arts. 37, 40, 195 e 201 da Constituição Federal, para dispor sobre a previdência social, e dá outras providências. [Brasília, DF: Presidência da República], 2005. Disponível em http://www.planalto.gov.br/ccivil_03/constituicao/Emendas/Emc/emc47.htm. Acesso em 20 nov 2019.

BRASIL - Ministério da Economia. Organograma. 2020. Disponível em: <https://www.gov.br/economia/pt-br/imagens/organograma_v11.pdf/>. Acesso em: 15 ago. 2019.

CHILE. Decreto ley ${ }^{\circ}$ 3.500. establece nuevo sistema de pensiones. [Santiago: Gobierno de la República de Chile], 1980. Disponível em:

<https://www.spensiones.cl/portal/institucional/594/articles-3832_recurso_1.pdf>. Acesso em: 20 mar. 2019. 
FRIEDMAN, Milton. Capitalismo e liberdade. São Paulo: Abril Cultural, 1984.

GRANEMANN, Sara. Estado e questão social em tempos de crise do capital. In: O AVESSO DOS DIREITOS: Amazônia e Nordeste em questão. Recife: Editora da UFPE, 2012.

INPA - Instituto Nacional de Pesquisas da Amazônia - Bosque da ciência. Manaus, 2012. http://bosque.inpa.gov.br/bosque/index.php/homepage/ Acesso em 02.08.19 MARX, Karl. O Capital: crítica da economia política. São Paulo: Abril Cultural, 1983. (Os economistas).

MOTA, Ana Elizabete. Cultura da crise e seguridade social. São Paulo: Cortez, 1995.

NETTO, José Paulo. Capitalismo monopolista e serviço social. São Paulo: Cortez,1992.

REPÚBLICA in DICIONÁRIO da língua portuguesa. CALDAS AULETE DIGITAL. Lexikon Editora Digital. 2010. Acesso em: 10 nov. 2019.

Universidade do Estado de Santa Catarina - UDESC Programa de Pós-Graduação em Educação - PPGE 